\title{
Italy: The Archaeology of Palaeoshorelines, Coastal Caves and Seafaring Connections
}

\author{
Elena Flavia Castagnino Berlinghieri, \\ Fabrizio Antonioli, and Geoff Bailey
}

\begin{abstract}
Watching a coast as it slips by the ship is like thinking about an enigma. There it is before you-smiling, frowning, inviting, grand, mean, insipid, or savage, and always mute with an air of whispering. Come and find out.

— Joseph Conrad, Heart of Darkness
\end{abstract}

\begin{abstract}
Italy has very few currently known finds of underwater archaeology from the Stone Age, despite a substantial history of geological and geoarchaeological investigation into sea-level change and archaeological investigations of underwater remains of coastal settlements and shipwrecks from later periods. Nevertheless, there are traces of prehistoric cultural activity in submerged coastal caves, open-air sites with stone tools and potsherds that have survived inundation, and Bronze Age stone-built structures that have been partially submerged by recent changes in relative sea level and give some measure of the potentially destructive effects of marine erosion. The tradition of geoarchaeological investigation into late
\end{abstract}

E. F. Castagnino Berlinghieri $(\bowtie)$

Dipartimento di Scienze Biologiche, Geologiche e Ambientali, Università di Catania, Catania, Italy

Soprintendenza per i Beni Culturali e Ambientali di Siracusa, Sicily, Italy

F. Antonioli

Italian National Agency for New Technologies,

Energy and Sustainable Economic Development

(ENEA), Rome, Italy

e-mail: fabrizio.antonioli@enea.it
Pleistocene and early Holocene sea-level change has provided detailed maps of palaeoshorelines that provide interesting insights into the likelihood of early sea crossings and connectivity between the Italian mainland and its major offshore islands and potential targets for the discovery of new archaeological finds. Moreover, maritime activities and coastal settlement have played an important role throughout Italian prehistory, including consumption of marine foods such as molluscs at the shore edge, sea travel to exploit the resources of offshore islands, agricultural dispersal, and the obsidian trade. These developments were under way at a time when sea levels were mostly lower than the present, and most of the relevant archaeological evidence is likely to 
be on palaeoshorelines that are now submerged, emphasising the need for new underwater investigations to fill this important gap in the archaeological record.

\section{Keywords}

Submerged caves · Palaeoshorelines ·

Offshore islands · Obsidian trade $\cdot$ Seafaring · Neolithic $\cdot$ Bronze Age

\subsection{Introduction}

Italy comprises the Italian Peninsula, the two largest islands in the Mediterranean, namely, Sicily and Sardinia, and over 300 smaller islands within its territorial waters, with a total coastline of c. $8000 \mathrm{~km}$. It faces four different seas: the Adriatic to the east between Italy and Croatia, the Ionian Sea to the south-east between Italy and Greece, the Tyrrhenian Sea to the west, and the Ligurian Sea to the north-west, and no point is further than $120 \mathrm{~km}$ from the nearest sea coast (Fig. 16.1). Its coastlines are also highly variable in terms of their present-day morphology and the width and character of the offshore shelf (Antonioli et al. 2017).

Yet, despite Italy's strongly maritime character, the probable importance of coastlines and sea crossings during prehistory, and the sensitivity of its coastal and island palaeogeography to the impact of relative sea-level change, underwater investigations have mainly concentrated on the remains of Classical and later periods such as shipwrecks and remains of harbours, cities or other shoreline structures submerged by tectonic movements and on the search for sea-level indicators. Only eight submerged prehistoric sites are currently known: one palaeontological find of late Pleistocene age but not certainly associated with artefacts or human activity, two Neolithic sites, and five Bronze Age structures. In this chapter, we examine the archaeological and palaeogeographical significance of sea-level change, describe the underwater material that is cur- rently known, and consider future directions of research.

\subsection{Palaeogeographical and Archaeological Context}

In broad terms, the lowering of sea level at the LGM (Last Glacial Maximum) had its main effect on the eastern side of the Peninsula, creating an extensive area of land in what is now the northern Adriatic basin between northern Italy and Croatia (Fig. 16.1). On the western side of Italy, the continental shelf exposed at low sea level was much narrower, but here sea-level change would have had important effects in joining together or isolating offshore islands including the important land masses of Sardinia and Sicily. Sardinia and Corsica formed a single, large land island at lowest sea level. Though it was not connected to the Italian mainland during the low sea-level stands of the late Pleistocene, it was separated only by a relatively narrow sea channel. It was also large enough to sustain a mammalian fauna that had evolved in isolation since earlier in the Pleistocene (Antonioli et al. 2011; Palombo et al. 2017).

Similarly, Malta would have formed a southern peninsula of Sicily (see Gambin, Chap. 17, volume), and the narrow channel between Sicily and southern Italy - the Strait of Messina, famous in Classical Mythology for its treacherous currents flowing between the twin hazards of Scylla and Charybdis - would have been connected to the mainland, but only intermittently at lowest sea-level stands (Antonioli et al. 2016). The distance to North Africa would also have been reduced at lowest sea-level stands, though sea crossings of at least 40-50 km would have been necessary, even at the Last Glacial Maximum.

Because of its complex geological history, the regional response to global sea-level changes has been highly variable in different parts of Italy. Tectonic uplift or subsidence plays a particularly prominent role in southern Italy and Sicily where plate boundaries associated with the collision of the African and the Eurasian Plates are associ- 


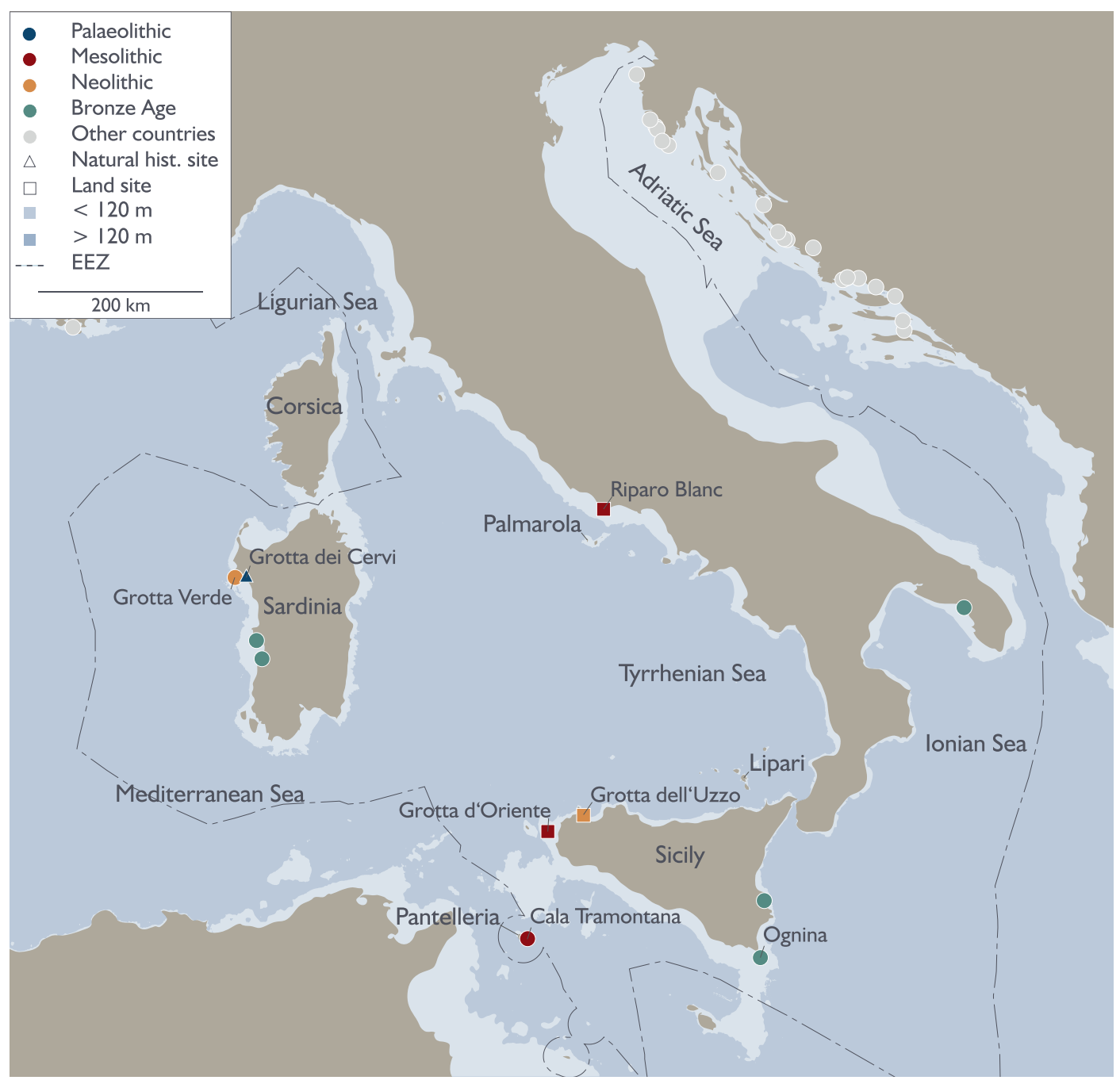

Fig. 16.1 Map of Italy showing distribution of underwater sites, key names and other places mentioned in the text. Site information from the SPLASHCOS Viewer http://splashcos-viewer.eu. Drawing by Moritz Mennenga

ated with intensive seismic and volcanic activity. These have resulted in considerable vertical movement of coastlines, compounded by regional variations in glacio-hydro-isostatic adjustments of the Earth's crust. Consequently, detailed geological studies have been devoted to unravelling the complex interplay between eustatic sea-level changes and isostatic and tectonic movements, making use of natural features such as beach deposits and cultural remains from later periods such as Roman fish tanks and including underwater features as well as those on land (Lambeck et al. 2004; Antonioli et al. 2006, 2011; Auriemma and Solinas 2009; Lambeck et al. 2011; Rovere et al. 2011a, b; Benjamin et al. 2017). These studies have important implications for palaeogeographic reconstructions of shoreline changes, the connectivity between the Italian Peninsula and its offshore islands, and the impact of sea-level change on the archaeological record. They play an important role in providing accurate maps of palaeoshorelines with which to investigate archaeological problems. 
Despite the few underwater finds currently known, nevertheless, the potential for the discovery of prehistoric remains is considerable. Sections of the Italian coastline are composed of limestone karst complexes with numerous caves, particularly in Sardinia and on the Ligurian coast in the north-west, along parts of southern Italy on both its Ionian and Tyrrhenian coasts, and in Sicily (Antonioli et al. 2017, Fig. 13.20). These karst geologies extend offshore with many underwater caves (see also Billard et al., Chap. 12, this volume; Galanidou et al., Chap. 19, this volume). Coastal caves above modern sea level in these areas have yielded important sequences of Palaeolithic occupation, human fossils, and evidence for the use of marine molluscs as food and for shell ornaments, in some cases dating to the Mousterian as far back as $115 \mathrm{ka}$, or with evidence of Mesolithic and Neolithic occupation in other cases (Blanc 1939, 1958/61; Blanc and Segre 1953; Stiner 1994, 1999; Mannino et al. 2007, 2011, 2012). Most of the evidence in these coastal caves was accumulated when sea level was lower than present, highlighting the importance of these now-submerged landscapes and palaeoshorelines in interpreting the known archaeology on land and charting the long-term history of shorelines and marine resources in the human economy. However, very few underwater caves have so far yielded relevant evidence, apart from two in Sardinia that have preserved remains of artefacts or fauna and other examples of potential importance discussed below.

Other issues that focus on the reconstruction of palaeoshorelines and underwater investigations are the development of trade in obsidian and the spread of early farming, both of which were under way during the Neolithic period at a time when relative sea level was still lower than the present. The obsidian trade is of special interest because the major sources of obsidian in the central Mediterranean are the Italian islands of Sardinia, Palmarola, Lipari, and Pantelleria (Castagnino Berlinghieri 2011), and obsidian from these sources was traded widely into mainland Italy and beyond and to North Africa (Tykot 1996). However, underwater finds that relate to these developments in seafaring, agricultural dispersal, and maritime trade are very limited and known only from Cala Tramontana on the island of Pantelleria, notable because the island was never connected to any adjacent land mass and was a major obsidian source, and from some partially submerged sites of the Bronze Age in Sardinia and southern Italy.

\subsection{Stone Age Archaeology: Karst Caves and Palaeoshorelines}

\subsubsection{Sardinia}

A number of caves on the rocky promontories around a small bay near Alghero in NW Sardinia have yielded faunal remains and traces of human activity. Two of these, Grotta Verde and Grotta dei Cervi, are partially submerged and contain deposits below sea level with human remains and Pleistocene fauna, respectively (Fig. 16.2).

\subsubsection{Grotta Verde}

Grotta Verde can only be reached by sea today, and its main entrance is a wide opening c. $90 \mathrm{~m}$ above sea level in the side of a steep cliff (Fig. 16.3; Lo Schiavo 1986). A tunnel drops steeply down to a partially flooded chamber, around the edges of which are niches between 8 and $10 \mathrm{~m}$ bpsl (below present sea level) with bone remains of human burials, Neolithic pottery of impressed cardial type, and some bones of domestic animals, mainly ovicaprid with fewer bones of pig and cattle (Fig. 16.4; Tanda 1980, 1987a, b; Atzeni 1981; Antonioli et al. 1996; Wilkens 2012). The ceramics indicate a date broadly between the 9th and 7th millennium BP, and the whole assemblage is consistent with ritual activity associated with burial rites. At this period, sea level was c. $20 \mathrm{~m}$ bpsl. Molluscs shells (Patella caerulea and Phorcus turbinatus) collected as food at the nearby Cala Vergine cave (on the east shore of Punta del Quadro; Fig. 16.2) and a human incisor from the Medusa Cave (both caves are above present sea level) have both been 


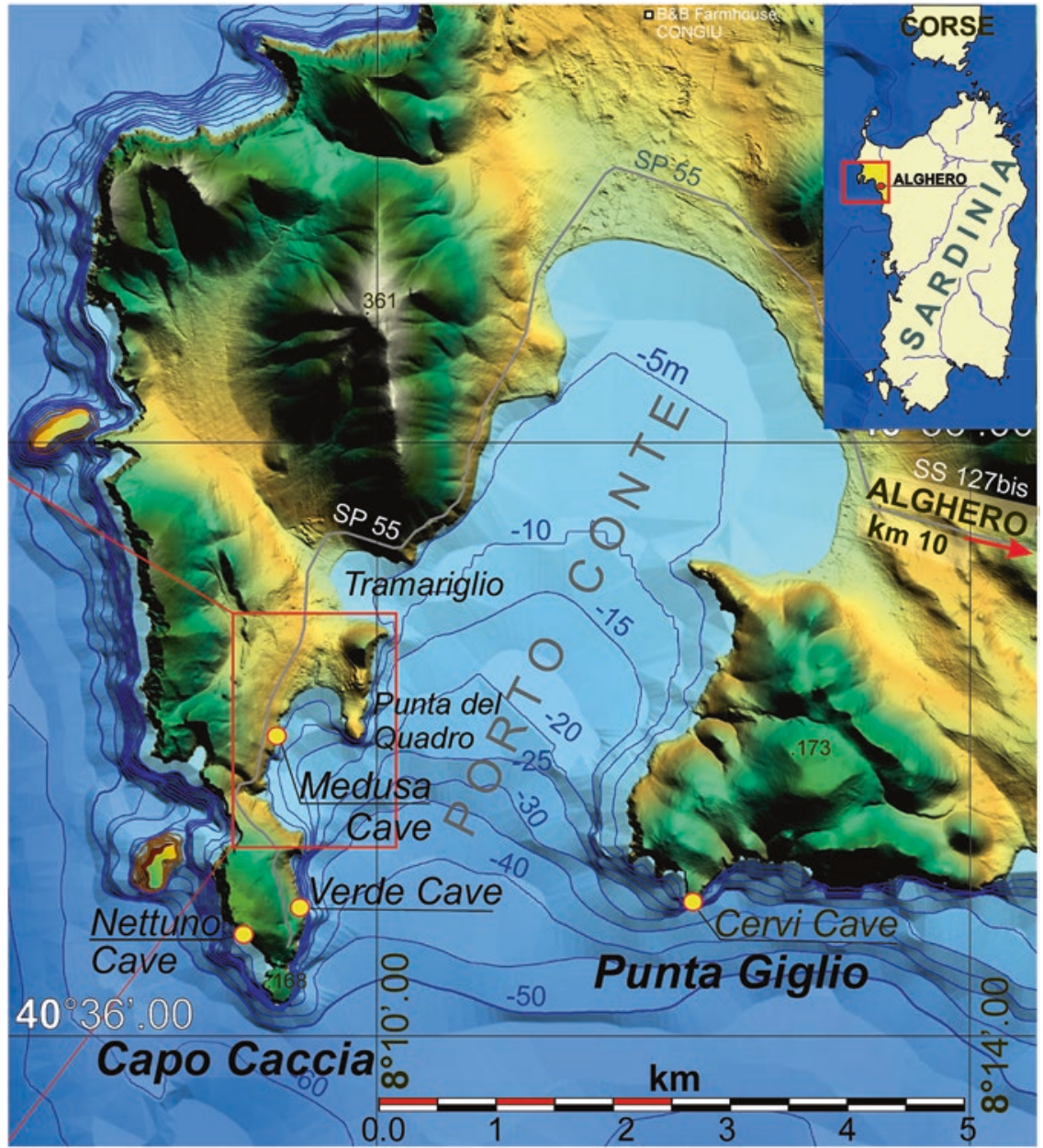

Fig. 16.2 Map of NW Sardinia showing the topography and bathymetry around the bay of Porto Conte and the location of Grotta Verde and Grotta dei Cervi. After Palombo et al. (2017, Fig. 1, p. 118). Reproduced with permission

directly radiocarbon-dated with similar readings of c. $7.4 \mathrm{ka}$ cal BP (Palombo et al. 2017), of similar date to the Grotta Verde remains.

\subsubsection{Grotta dei Cervi}

The Grotta dei Cervi is a cave opening at present sea level and contains a partially submerged bone breccia with remains of a Pleistocene deer, Praemegaceros cazioti (Fig. 16.5), a member of an endemic Pleistocene fauna that has persisted on the island since at least the Middle Pleistocene and is well represented in other fossiliferous cave deposits on Sardinia (Palombo et al. 2017). The Grotta dei Cervi deposit was formed when sea level was substantially lower than present, with a date on a deer tooth of $11.8 \mathrm{ka}$ cal BP. The cave was subsequently partly eroded and submerged. When sea level was lower, the cave could have been approached up a gently inclined slope from the surrounding coastal plain, and the animal appears to have died there of natural causes. There are tooth marks on the bones caused by rodents or other deer (who derive calcium by chewing bones) but no evidence of cut marks to suggest human intervention (Palombo et al. 2017).

These caves are of particular relevance to discussions about earliest human entry into Sardinia and the possibility of Pleistocene sea crossings. 


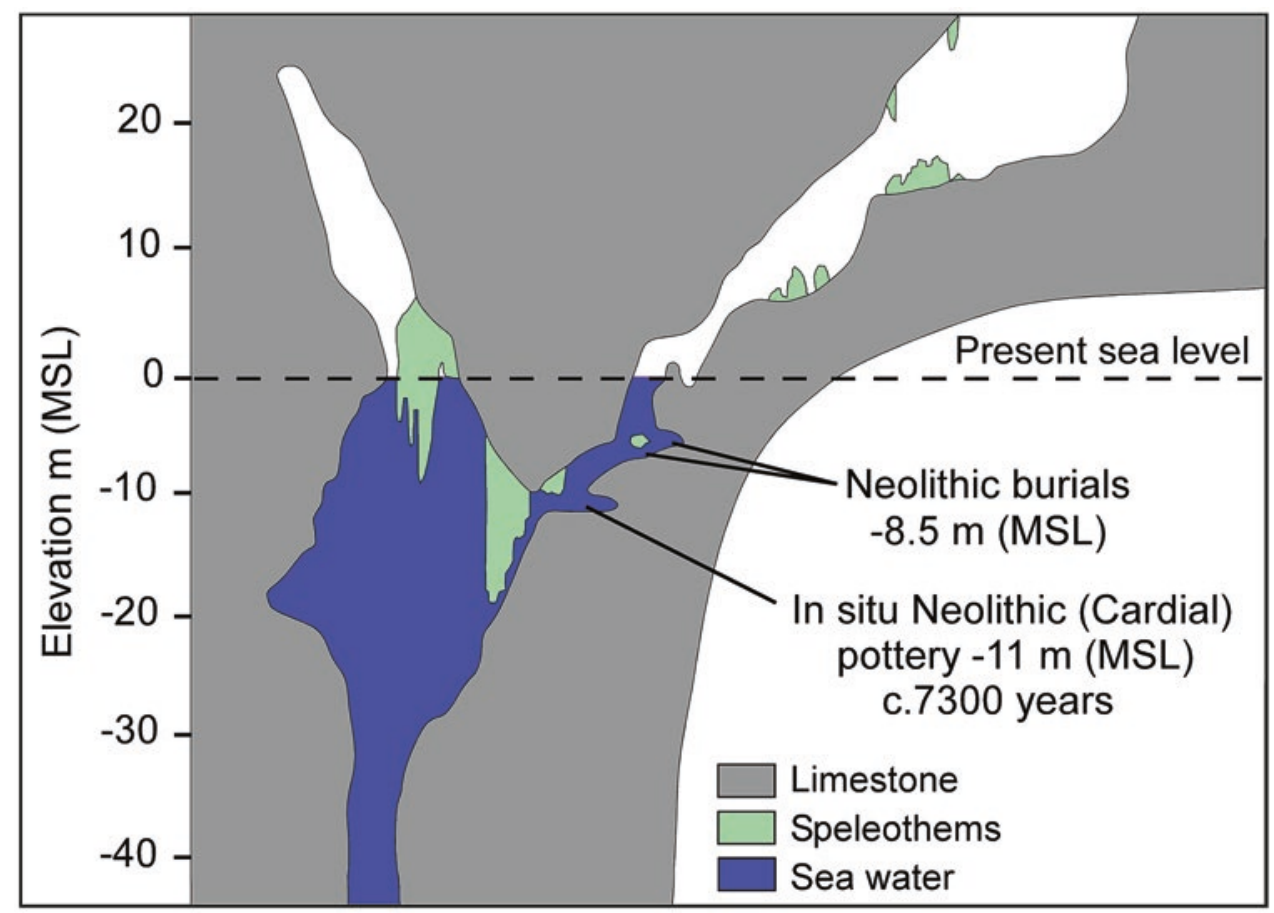

Fig. 16.3 Cross section of the Grotta Verde showing the location of the Neolithic necropolis. After Antonioli et al. (1996) and Palombo et al. (2017, Fig. 6, p. 123). Reproduced with permission
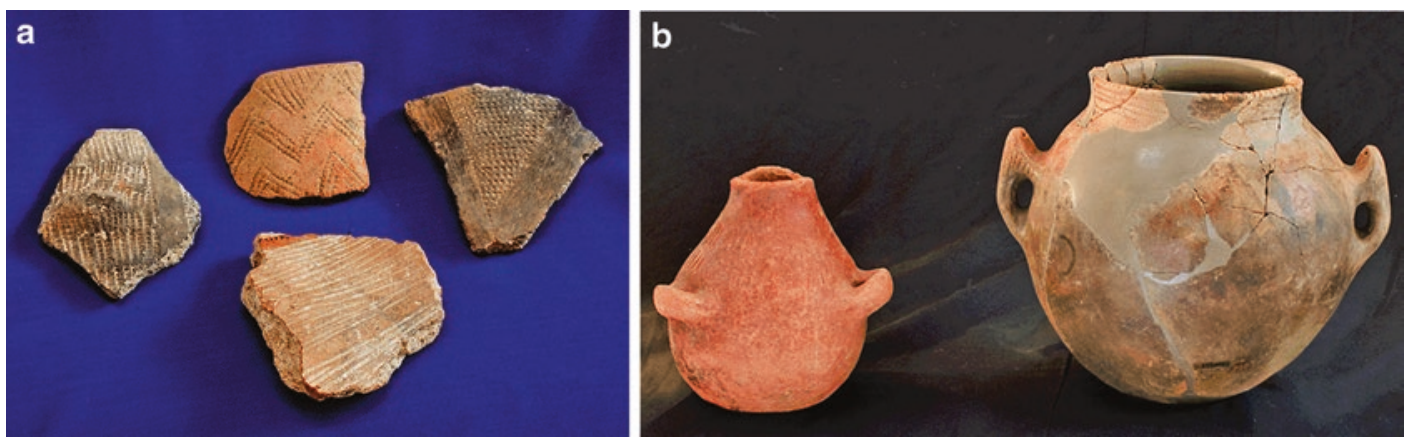

Fig. 16.4 Neolithic pottery from the Grotta Verde. (a) Potsherds with cardial impression. (b) Globular vessels with pierced lugs. The vessel on the right has cardial-impressed decoration of parallel wavy lines on the collar. Photos courtesy of Museo Nazionale "Giovanni Antonio Sanna”, Soprintendenza per i Beni Archeologici di Sassari e Nuoro

Recent research on sea-level markers demonstrates that the Earth's crust in this region has been quite stable over the past $125 \mathrm{kyr}$ (Antonioli et al. 2011) and that palaeoshorelines can be reconstructed with some confidence. These show that, at the time of the Last Glacial Maximum, Sardinia and Corsica were combined as a single land mass. However, movement from the Italian mainland would have required a sea crossing of $12 \mathrm{~km}$ across a narrow strait (Fig. 16.6). There are claims for earlier Stone Age finds in Sardinia, but these remain controversial and are not universally accepted because of doubts about stratigraphic integrity and chronology (Klein Hofmeijer et al. 1989; Mussi 2002; see also Dawson 2013). The implication of the evidence from the Alghero 


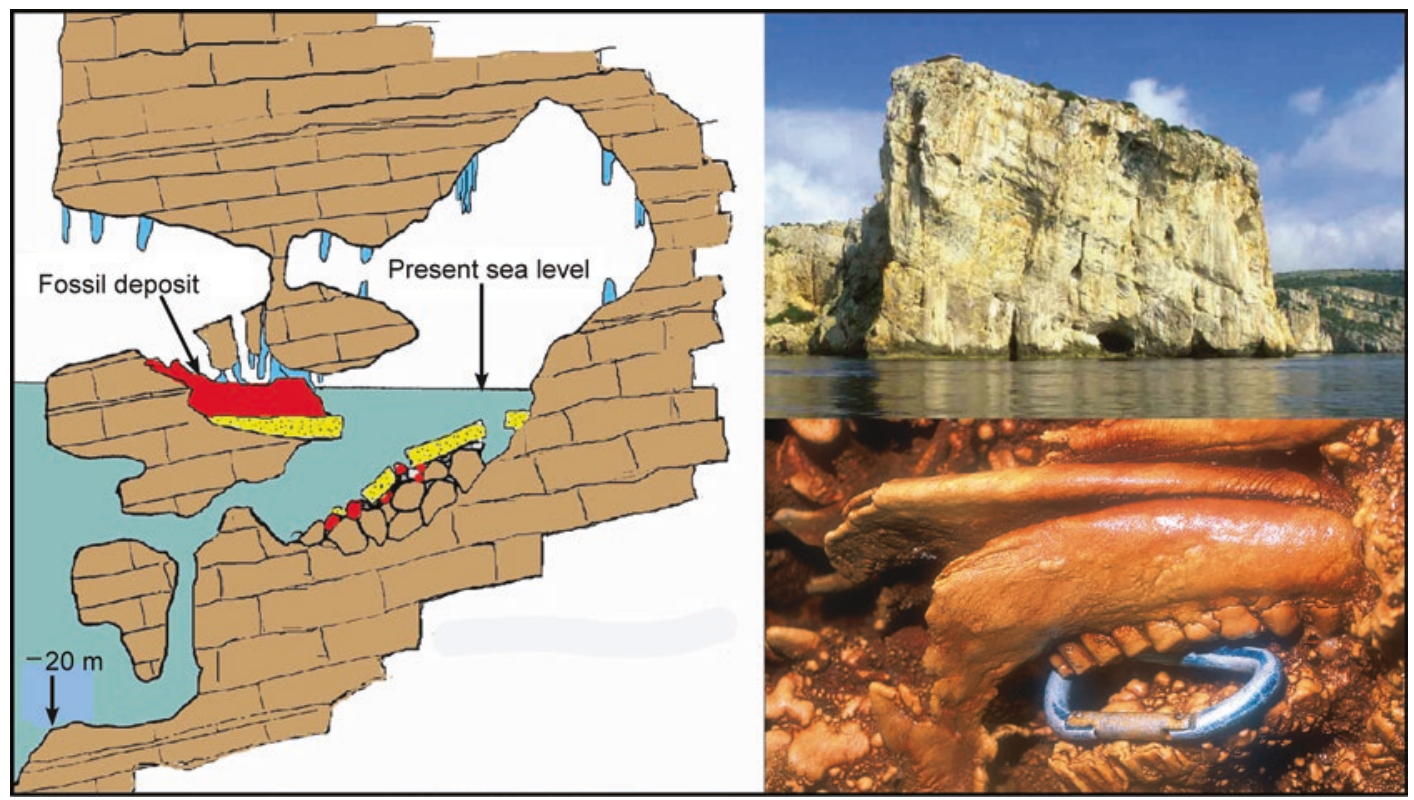

Fig. 16.5 The Grotta dei Cervi showing a cross section of the site and its deposits, and a mandible of Praemegaceros cazioti in situ in the breccia deposit. After Palombo et al. (2017, Fig. 6, p. 123). Reproduced with permission

caves is that humans were not present during the Pleistocene and that the sea crossing was a deterrent to human entry until the Mesolithic period, when the first unequivocal archaeological evidence appears (Floris et al. 2012; Palombo et al. 2017 , p. 118). However, the question of the earliest date of human entry remains unresolved, and the search for underwater finds may help to produce new and relevant discoveries.

\subsubsection{The Tyrrhenian Coast}

On the opposite side of the strait from CorsicaSardinia, reconstruction of palaeoshorelines shows that the Tuscan islands of Elba and Pianosa formed a single land mass attached to the Italian mainland at the Last Glacial Maximum and for some millennia afterwards (Fig. 16.7). Epigravettian (late Upper Palaeolithic) material on Pianosa is consistent with access by land at that time (Ducci and Perazzi 1998, 2000). Subsequently, the island was cut off by a sea crossing of c. $10 \mathrm{~km}$ and appears to have been abandoned, judging by the absence of Mesolithic material, only to be reoccupied during the Neolithic period, when seafaring is widely in evidence in the wider Mediterranean. Here too the implication is that sea crossings of $10 \mathrm{~km}$ or more were a deterrent to sea crossings until quite a late period in the prehistory of the region. But, as in Sardinia, the possibility that new archaeological sites including underwater remains will be discovered to fill some of the gaps in the archaeological record should be recognised.

Further south, in the Monte Circeo massif on the Latium shoreline, the rockshelter of Riparo Blanc contains Mesolithic occupation with evidence of food remains dominated by shells of marine molluscs and echinoderms, some fish bones, and rare terrestrial fauna (Colonese et al. 2011). This rockshelter is above sea level, but a lower cavity (Cala dell'Alabastro), accessible only from underwater, exists offshore and has yet to be explored (Fig. 16.8). Moreover, the tectonic stability of the area over the past 125,000 years (Ferranti et al. 2006) means that palaeoshorelines at successive periods can be reconstructed with some confidence (Fig. 16.9). 
Fig. 16.6 Map showing

the coastal

palaeogeography of

Sardinia and Corsica at

the Last Glacial

Maximum and the sea crossing to the Italian mainland. After

Palombo et al. (2017,

Fig. 9, p. 125).

Reproduced with permission

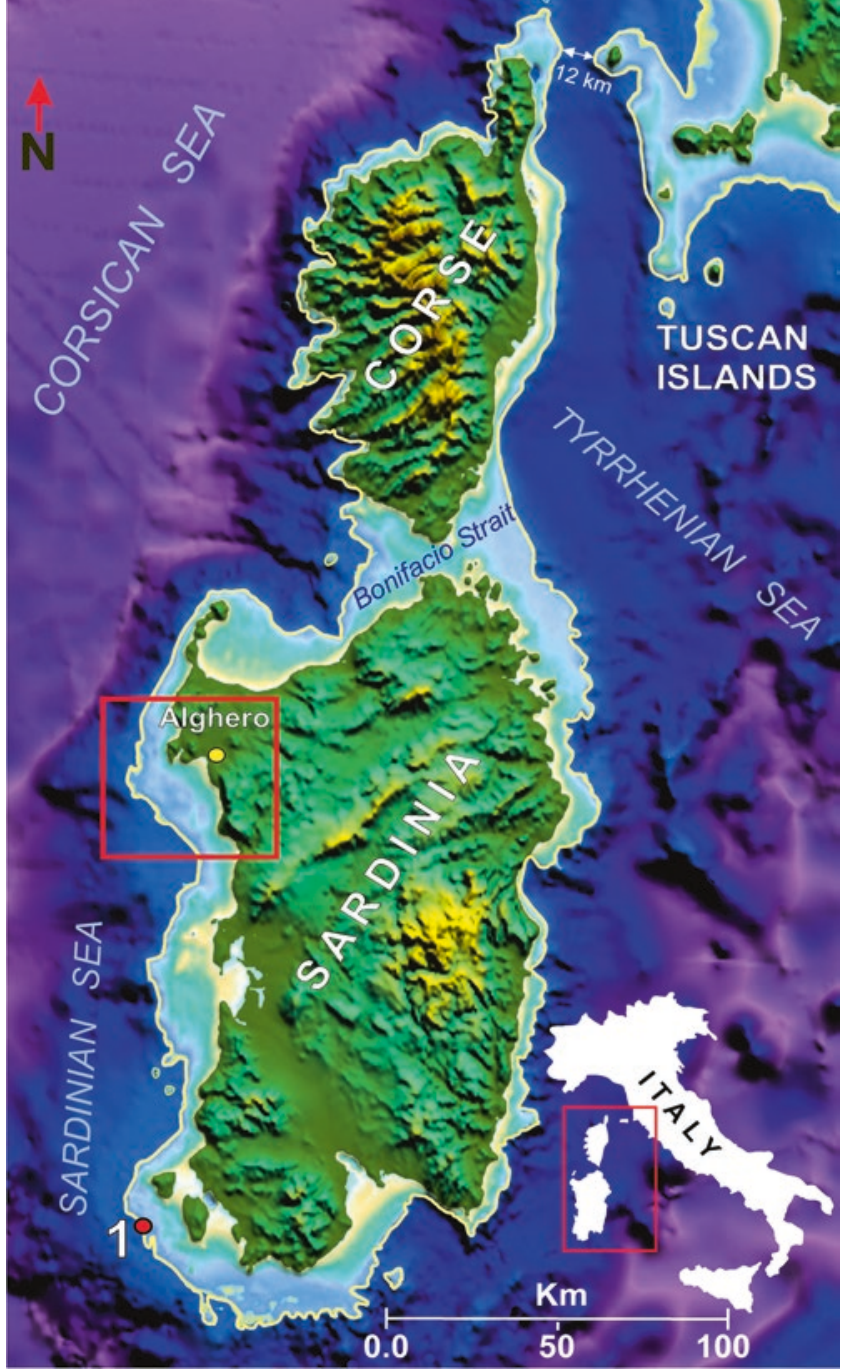

\subsubsection{Sicily}

Along the northern coast of Sicily and the offshore Ègadi Islands to the west, there are onshore coastal cave occupations dating from about 16,000 cal BP onwards, with late Upper Palaeolithic (Final Epigravettian), Mesolithic, and Neolithic levels, notably at Grotta d' Oriente on the island of Favignana (mainly Upper Palaeolithic and Mesolithic at a time when the island was still attached to Sicily) and at Grotta dell'Uzzo on Sicily (mainly Mesolithic and Neolithic) (Tusa 1996, 1999). These sites show progressive isolation and abandonment of the islands with sea-level rise and variable emphasis on consumption of molluscs or other marine foods, their importance increasing through time as sea level rose close to the present level (Compagnoni 1991; Bonfiglio and Piperno 1996; Mannino et al. 2007, 2011, 2012). From the point of view of underwater finds, the main interest of this region is the possibility of finding submerged caves with underwater archaeological evidence. The cave of Ficarella just below Grotta dell'Uzzo is one such possibility and would have overlooked an inlet now at $-26 \mathrm{~m}$, which would have been available during the late Mesolithic and early Neolithic (Fig. 16.10). 


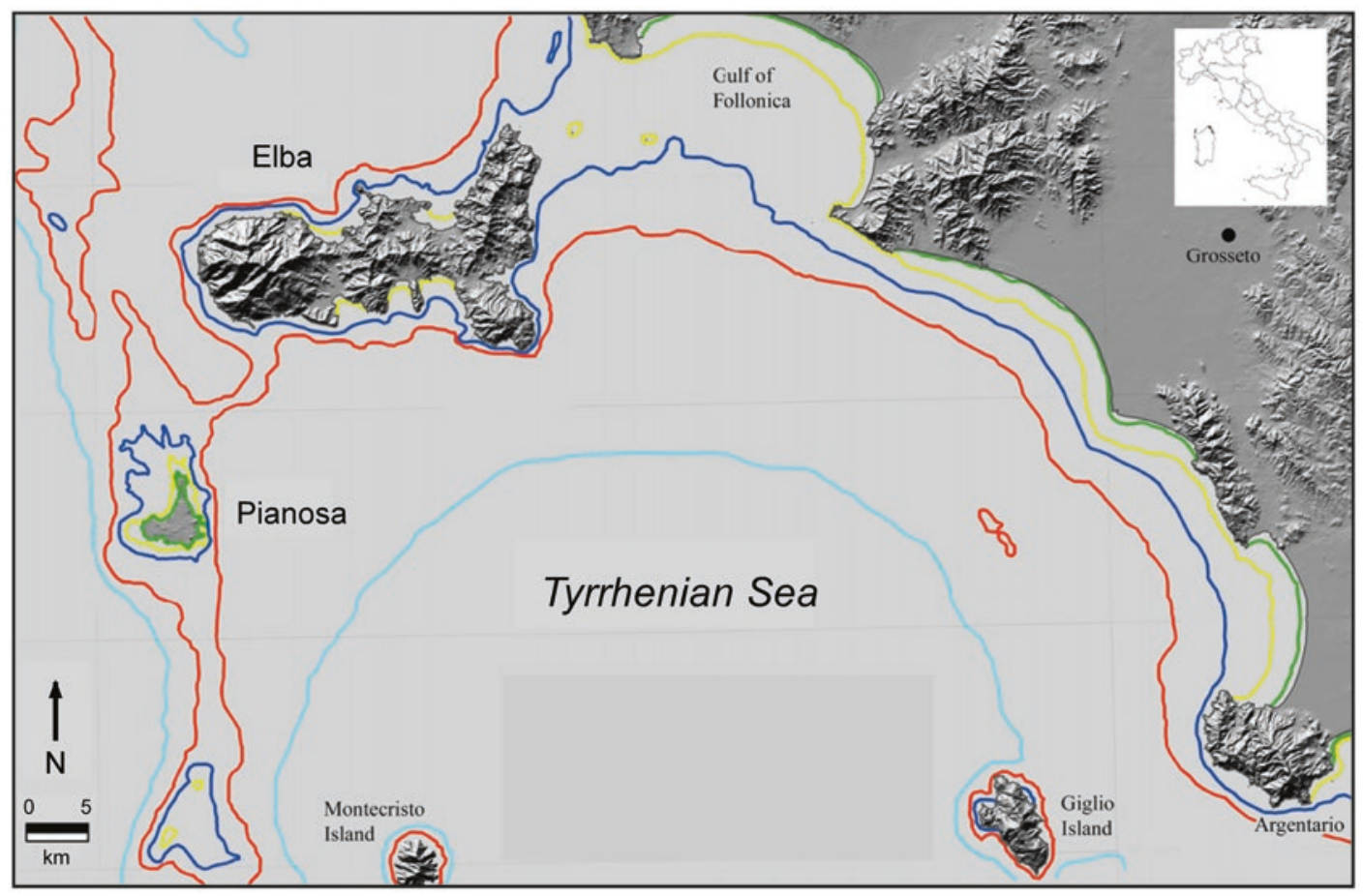

Fig. 16.7 The coastline of northern Lazio showing the relationship between the Italian mainland and the islands of Elba and Pianosa at different sea levels. Shoreline positions are based on bathymetry from GEBCO, adjusted for glaciohydro-isostatic effects according to the model of Lambeck et al. (2011). Dark blue: Mesolithic coastline (8 ka cal BP). Red: Upper Palaeolithic coastline (11 ka cal BP). Light blue: LGM coastline (22 ka cal BP)

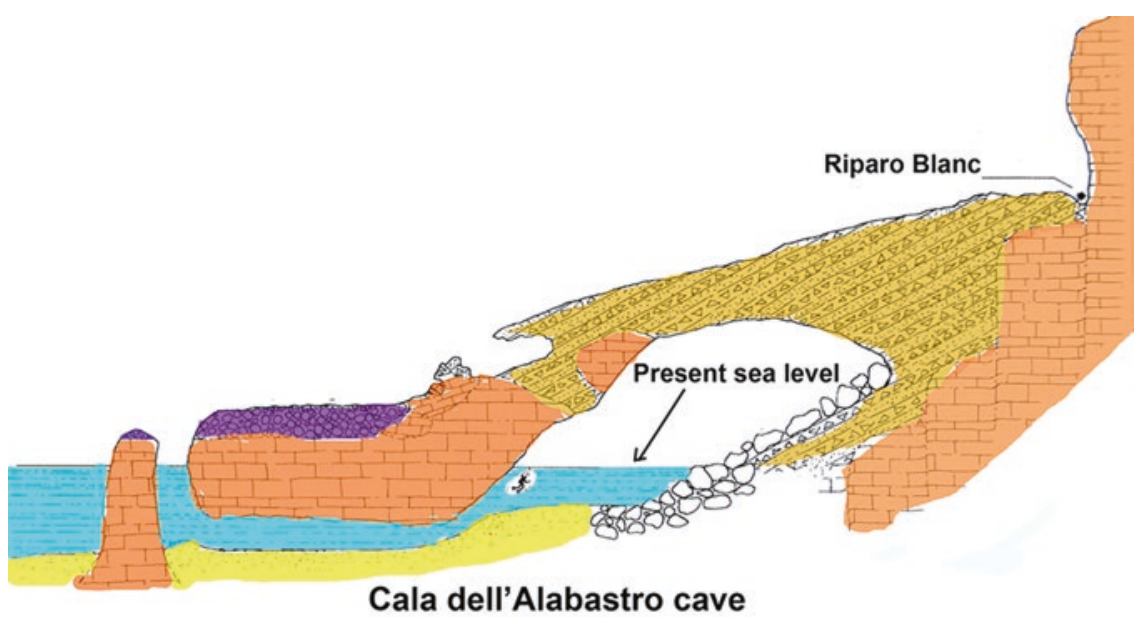

Fig. 16.8 Cross section of the shoreline on Monte Circeo showing the location of the Riparo Blanc rockshelter above present sea level, which has archaeological deposits, and the partially submerged cave of Cala dell'Alabastro. After Ferranti and Antonioli (1994) 


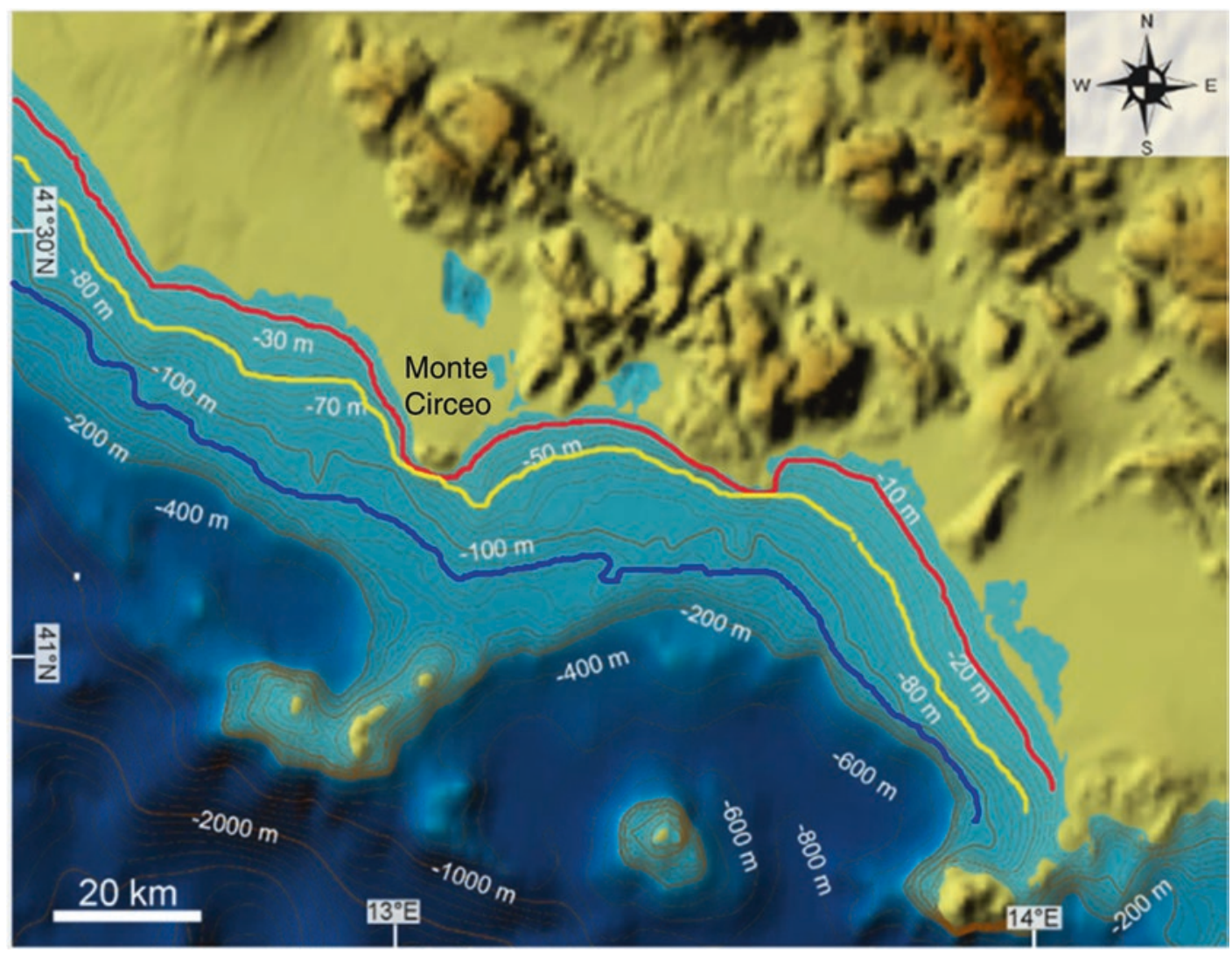

Fig. 16.9 The coastline of central Lazio showing palaeoshorelines for the LGM at $22 \mathrm{ka}$ (dark blue line), the Mesolithic at $11 \mathrm{ka}$ (yellow line), and the Neolithic at $8 \mathrm{ka}$ (red line). Location of shorelines is based on GEBCO bathymetry adjusted for the Lambeck et al. (2011) model

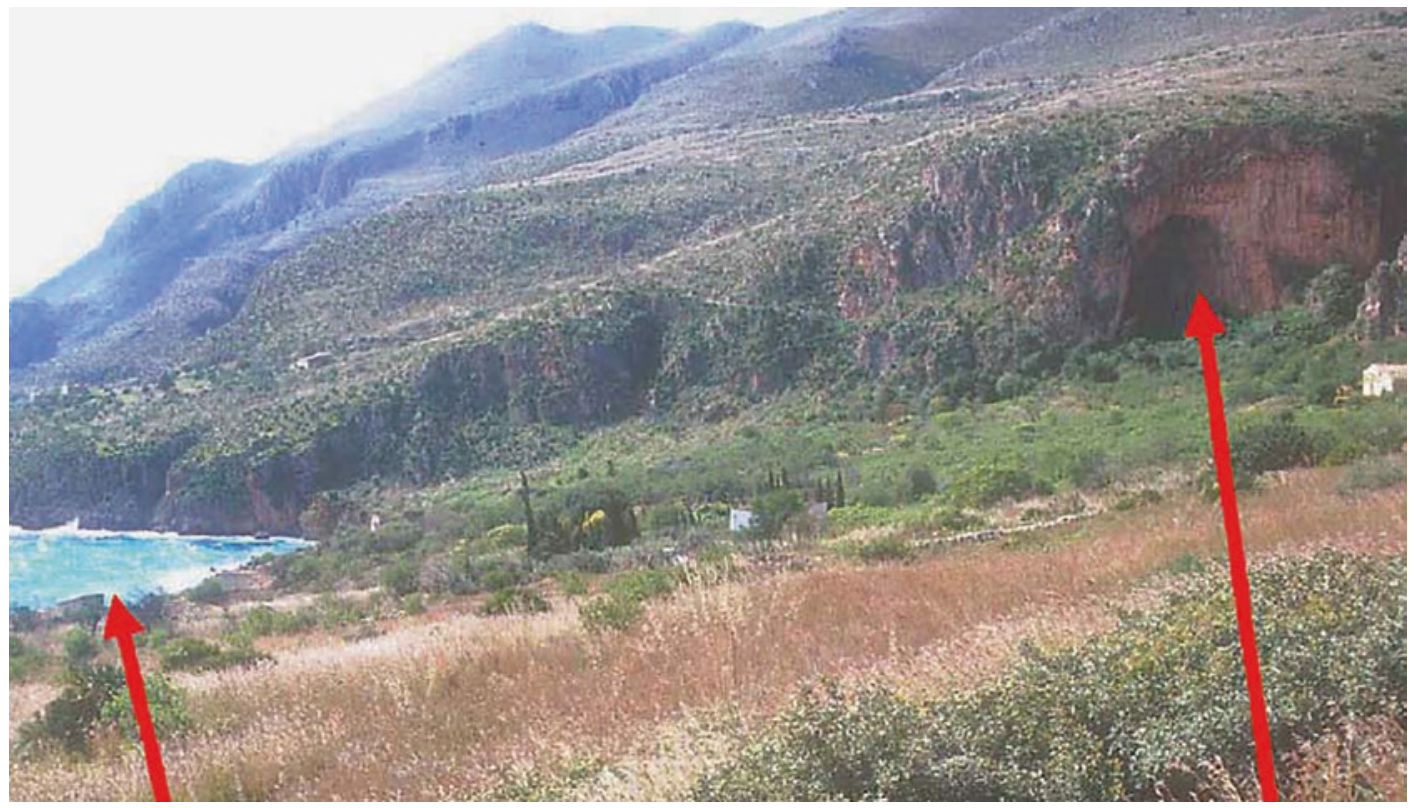

Fig. 16.10 Grotta dell'Uzzo, marked by the red arrow on the right, looking south, with the position of the submerged cave of Ficarella shown by the red arrow on the left. See Antonioli (1997) for further detail. Photo by Fabrizio Antonioli 


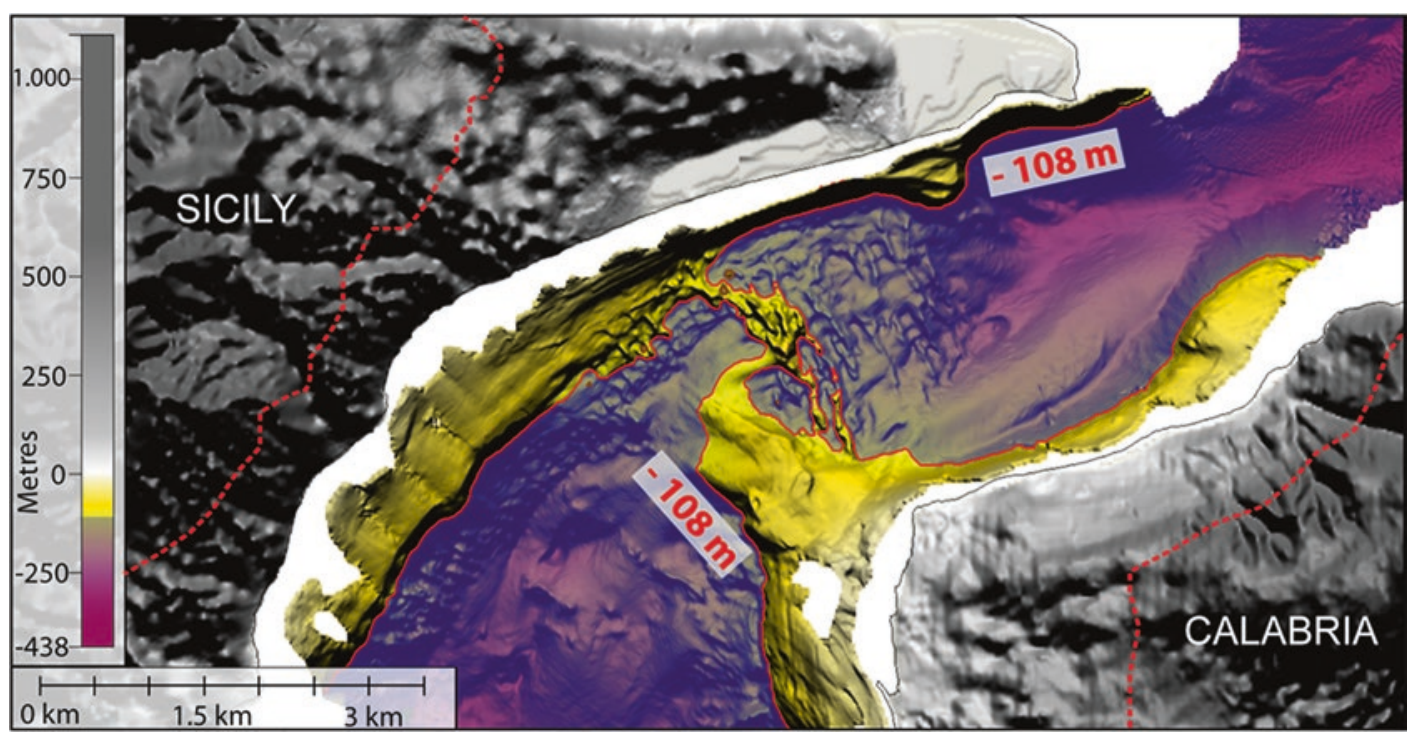

Fig. 16.11 Reconstruction of the palaeogeography of the Strait of Messina showing the land bridge that would have existed at the lowest sea-level stand of the LGM (at $-108 \mathrm{~m}$, shown by the continuous red line). The modern coastline is shown by a grey line, and the dotted red line indicates the coastline during the high sea-level stand of MIS 5.5. After Antonioli et al. (2016, Fig. 7)

The submerged sill in the Strait of Messina is located today at a minimum depth of $81 \mathrm{~m}$ below present sea level and represents the only connection between Sicily and mainland Italy (and thus Europe) during the last lowstand, when the sea level locally stood at about $-126 \mathrm{~m}$. Detailed analysis combining bathymetry, underwater geological investigations, modelling of eustatic sea-level change, and evidence of tectonic movements demonstrates the emergence of the sill as a narrow land bridge for a period of about 1500 years between 21.5 and $20 \mathrm{ka}$ cal BP (Fig. 16.11; Antonioli et al. 2016). If allowance is made for the accumulation of a $20 \mathrm{~m}$ thickness of sediments on the seabed which were subsequently eroded away, and hence for a shallower sill than today, the time interval for a dry land connection between mainland Italy and Sicily would have been c. $27-17 \mathrm{ka}$ cal BP. Despite the presence of an ancient Pleistocene fauna of dwarf elephants and hippo on Sicily, and claims for Lower and Middle Palaeolithic stone tools, radiocarbon dating of stratified palaeontological and archaeological data shows that the earliest reliable evidence for human presence only appears during and after this time interval of 27-17 ka, along with the introduction of a modern fauna including red deer (Cervus elaphus) and wild ass (Equus hydruntinus) (Antonioli et al. 2016). The shortest sea crossing today is only $4 \mathrm{~km}$ at present sea level and is notoriously dangerous for seafaring, memorably symbolised in the famous myth of Scylla and Charybdis. When sea level was lower, the crossing distance would have been even shorter, but palaeotidal modelling demonstrates turbulent currents of 17 knots, c. 20 miles per hour (Antonioli et al. 2016, pp 121-124), indicating even more hazardous sea conditions than today-presumably sufficient to deter any sea crossing in the Palaeolithic period.

\subsubsection{Pantelleria}

\subsubsection{Cala Tramontana}

Pantelleria is a small island lying $20 \mathrm{~km}$ southwest of Sicily on the shortest route between Tunisia and Sicily and is famous as a major source of obsidian exploited during the Neolithic and later from about 7000 years onwards. The submerged site of Cala Tramontana was discovered during underwater 


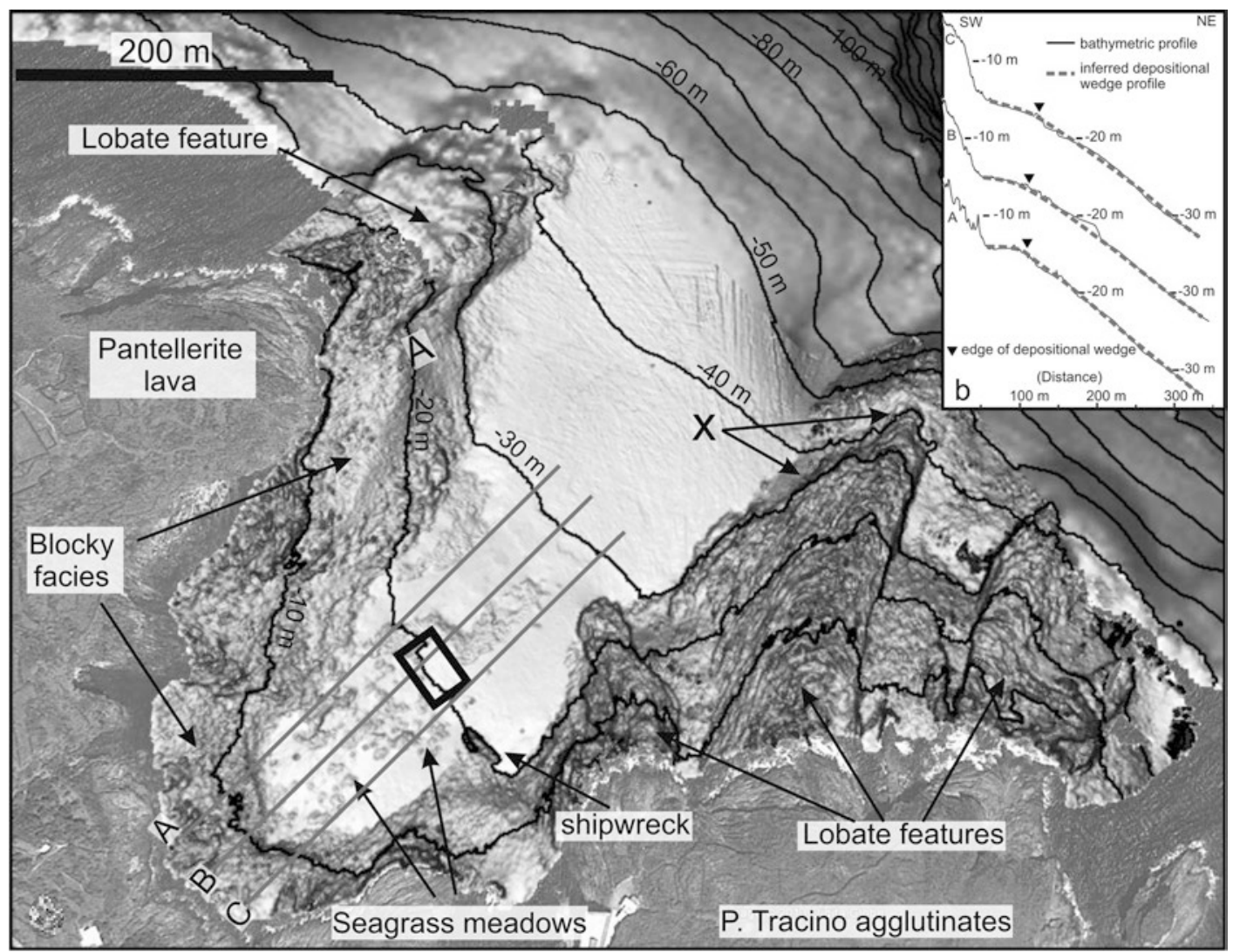

Fig. 16.12 Relief map of Cala Tramontana showing the bathymetry of the bay and the location of archaeological and geomorphological features. The black box marks the area of the prehistoric finds. After Abelli et al. (2016, Fig. 4). Reproduced with permission

investigation of a shipwreck. High-resolution bathymetry and scuba diving resulted in the discovery of a submerged assemblage of 770 artefacts at a depth of $18-21 \mathrm{~m}$, mostly made on locally available flint but including some made on local obsidian (Fig. 16.12; Abelli et al. 2016). The assemblage is based on a simple core and flake technology consistent with expedient exploitation of local raw materials during short-lived visits to the island (Fig. 16.13). Reconstruction of the now-submerged palaeoshoreline shows that conditions were quite different from the present-day coastline, offering a shallow, protected bay suitable for access by boat, whereas the modern shoreline consists of steep cliffs. Dating is only possible by indirect means, using the eustatic sea-level curve, modi- fied to take account of estimates of vertical tectonic movement related to volcanic activity, and gives a date between 9600 and 7700 years ago. This is the earliest date for human presence on the island and clear evidence for a preNeolithic sea crossing.

\subsection{Bronze Age Finds}

\subsubsection{Sardinia}

\subsubsection{Nuraghe of Funtana Meiga and Marceddi Lagoon}

Sardinia is well known for its many thousands of Bronze Age circular stone towers, or Nuraghe. Most are on dry land, but two examples are 


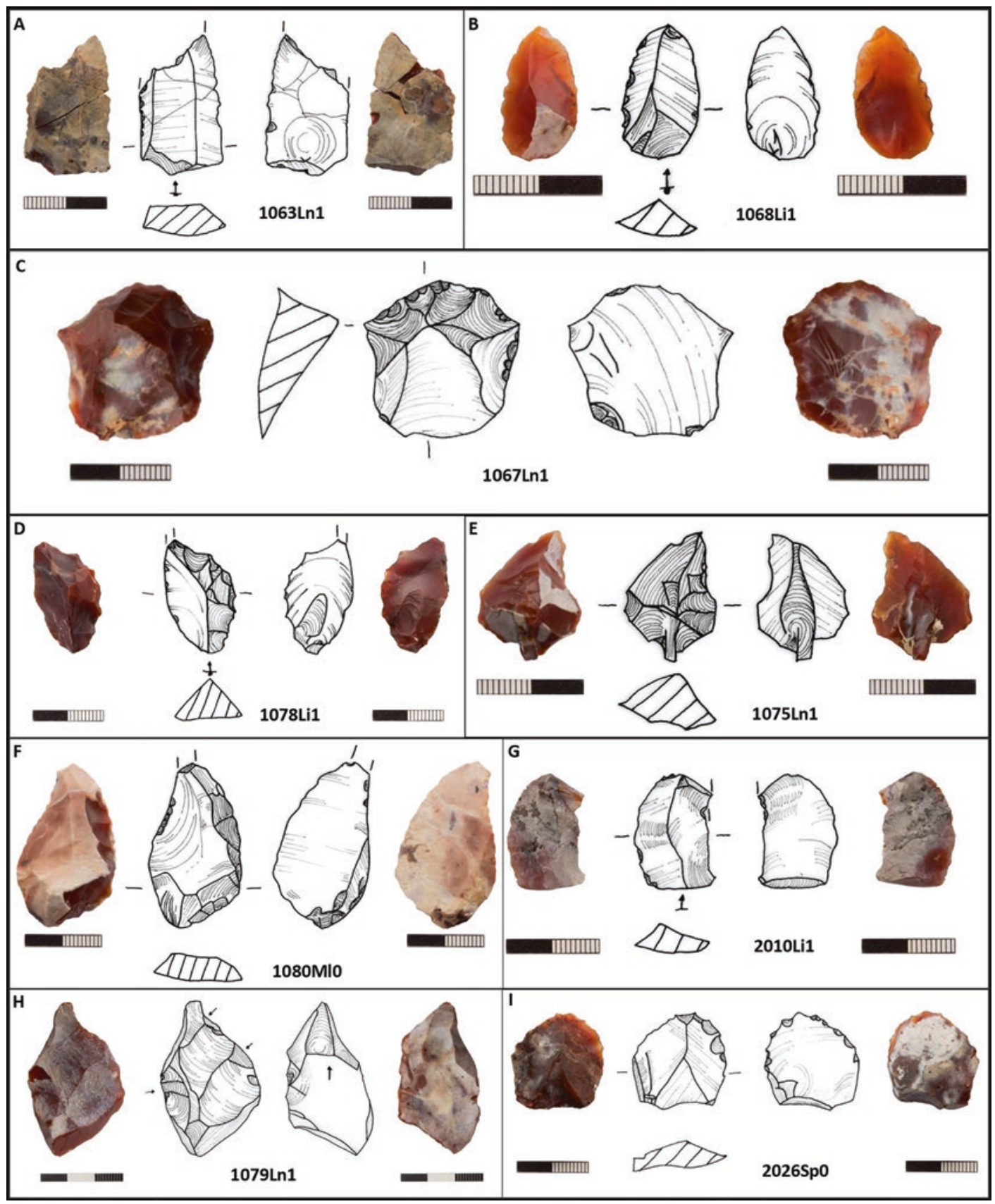

Fig. 16.13 A selection of prehistoric stone tools from the submerged site of Cala Tramontana. After Abelli et al. (2016, Fig. 5). Reproduced with permission 


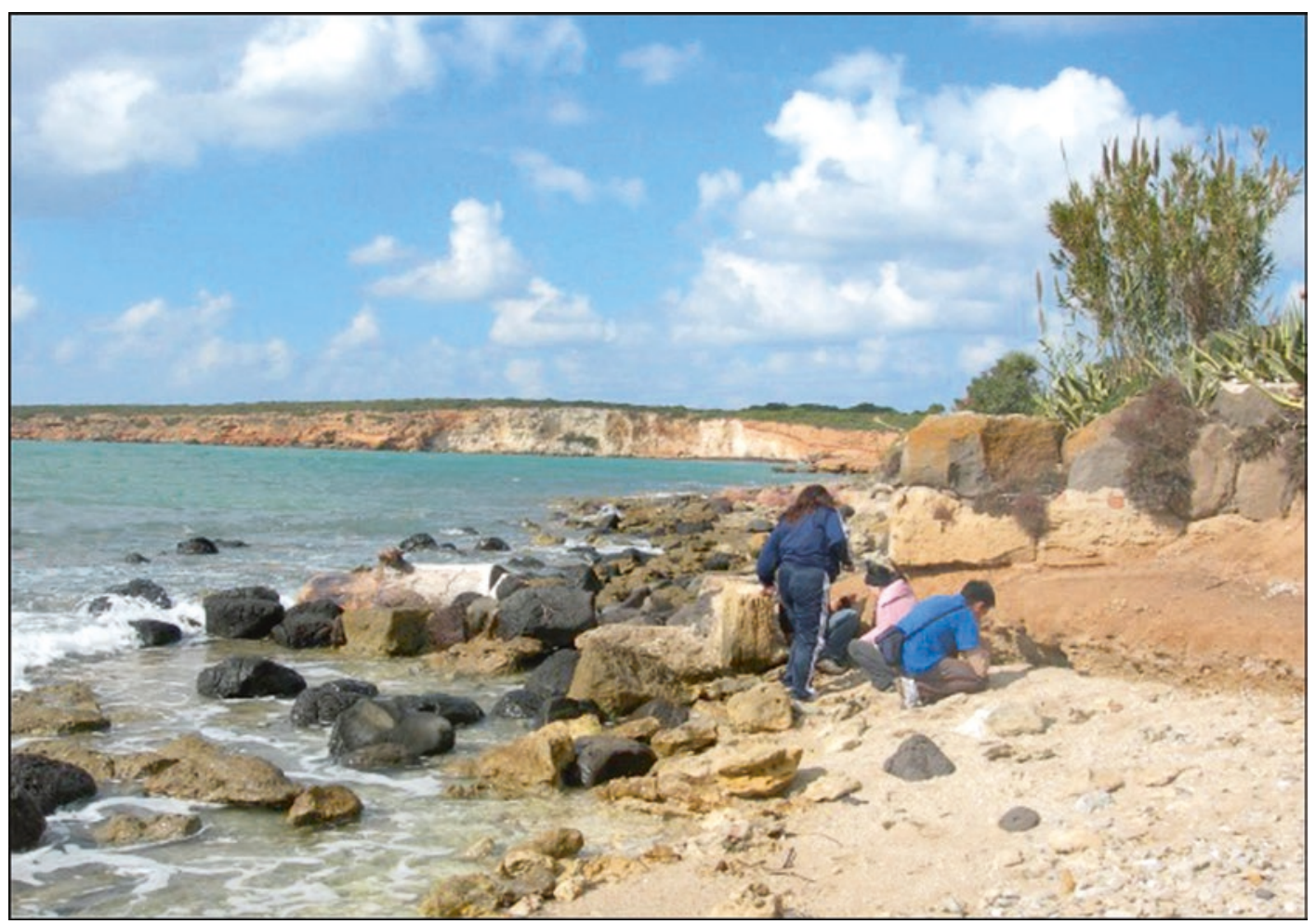

Fig. 16.14 Location and view of the site of Funtana Meiga in western Sardinia. Photo courtesy of Rita Melis

known on the coast at Funtana Meiga (Fig. 16.14) and Marceddi Lagoon. In both cases, the base of the tower is now below sea level, at -0.5 to $-1.0 \mathrm{~m}$ bpsl and $-1.0 \mathrm{~m}$ bpsl, respectively (Depalmas and Melis 2010; Melis pers. comm. 2013), indicating minor changes of relative sea level since the time of their construction.

\subsubsection{Sicily}

\subsubsection{Rock Cut Tombs of Ognina and Thapsos}

Both sites are in south-east Sicily and are partially submerged, demonstrating minor changes of relative sea level of 1-2 $\mathrm{m}$ over the past 3000 years and the effects of marine erosion. Ognina is a rock cut chamber tomb located on a former small peninsula connected to the mainland by a narrow rocky isthmus which is now sub- merged (Fig. 16.15; Scicchitano et al. 2008). Thapsos is a Middle Bronze Age necropolis on the Magnisi Peninsula, with a rock cut tomb that has been partially submerged and eroded (Fig. 16.16).

\subsubsection{Apulia}

\subsubsection{The Fortified Settlement of Scalo di Furno}

Scalo di Furno is located on the south-west Ionian coastline of Apulia (the heel of Italy), facing the Ionian Sea. It is a fortified settlement occupied for a period of more than 1000 years, beginning in the early Middle Bronze Age c. 1800 with local, handmade impasto pottery, some Late Helladic IIIA-IIIC sherds probably originating from Greece (or from the Aegean Region), and bronze objects (Lo Porto 1990). Part of the settlement has been submerged, and underwater 


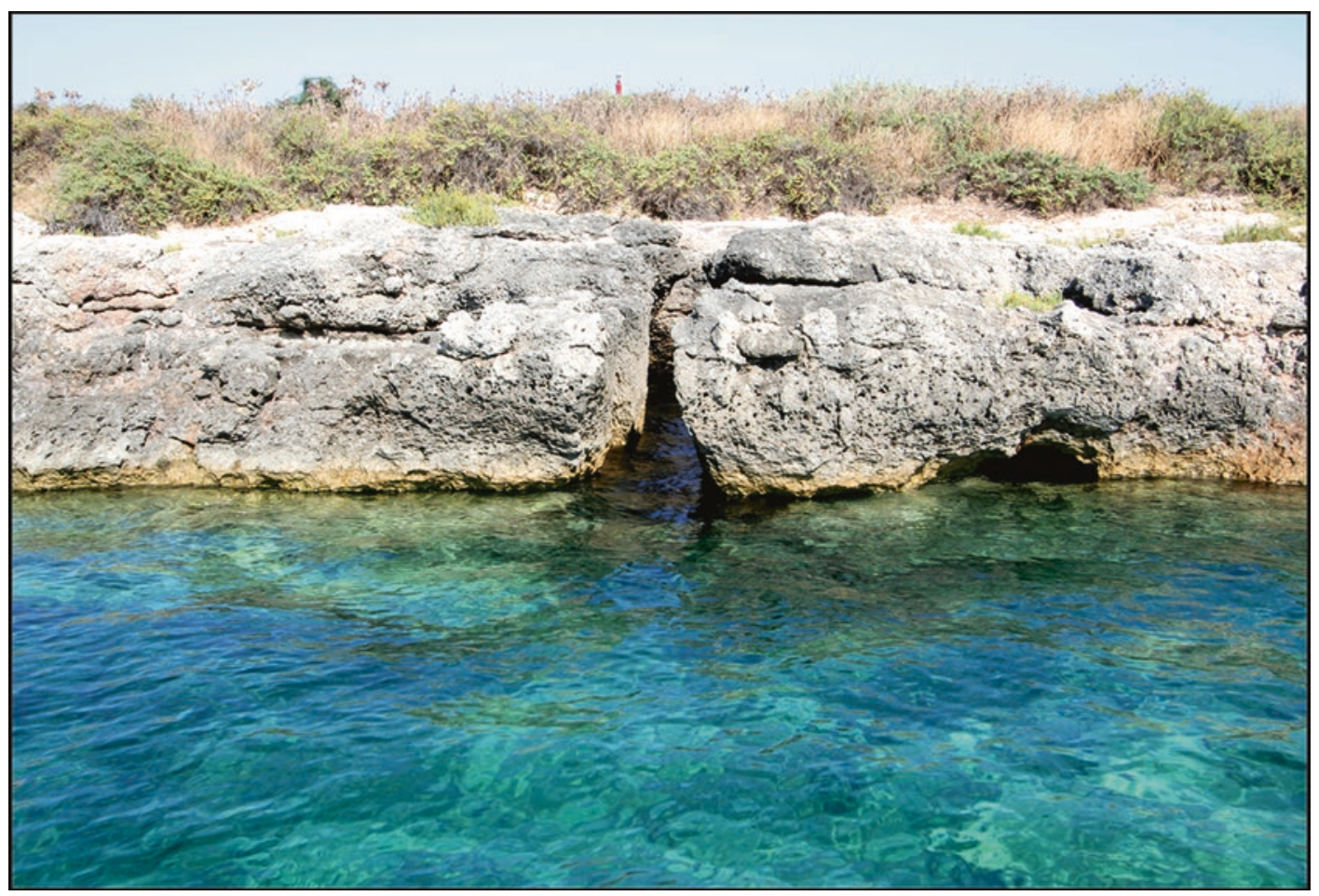

Fig. 16.15 The now-submerged entrance to the tomb of Ognina. After Scicchitano et al. (2016)

archaeological survey has revealed the remains of a submerged wall, c. $17 \mathrm{~m}$ long by $5 \mathrm{~m}$ wide and $1 \mathrm{~m}$ high, which represents part of the original fortified wall (Scarano et al. 2008; Scarano 2011; Alfonso et al. 2012). Also present at a depth of c. $-3.5 \mathrm{~m}$ on the seabed is an area of $2000 \mathrm{~m}^{2}$ with the remains of a flagstone floor and archaeological deposits containing hundreds of impasto sherds typical of the local Middle Bronze Age and many fragments of animal bone.

\subsection{Conclusion}

Investigation of Italy's submerged prehistoric archaeology is still at a comparatively early stage, and while there is a well-established tradition of underwater archaeological investigation, it has been largely focussed on the Bronze Age and Classical periods. At present, there are very few underwater finds from the Stone Age, and they are located mainly on the western coast of the
Italian Peninsula and its offshore islands. Even here, they are widely scattered, while the Adriatic coastline is a complete blank (see Radić Rossi et al., Chap. 18, this volume). Nevertheless, there is considerable scope for future discoveries, and the finds that are known provide some important pointers for the future.

First, there is a very substantial foundation of geological and geophysical knowledge and expertise about relative sea-level change, the changing palaeogeography of the submerged landscape, and the configuration of palaeoshorelines. These already provide intriguing indicators about the isolation or connectivity of offshore islands resulting from late Pleistocene and early Holocene sea-level change and the possibility of sea crossings during the late Palaeolithic and Mesolithic periods.

These palaeogeographic reconstructions also provide a useful starting point for identifying target areas for more detailed underwater investigation. Underwater coastal caves are an obvious 
Fig. 16.16 The necropolis of Thapsos showing the location of the partially submerged tomb (a). Photo showing the remains of the main sub-circular chamber and a series of niches cut into the bedrock (b). After Scicchitano et al. (2008)
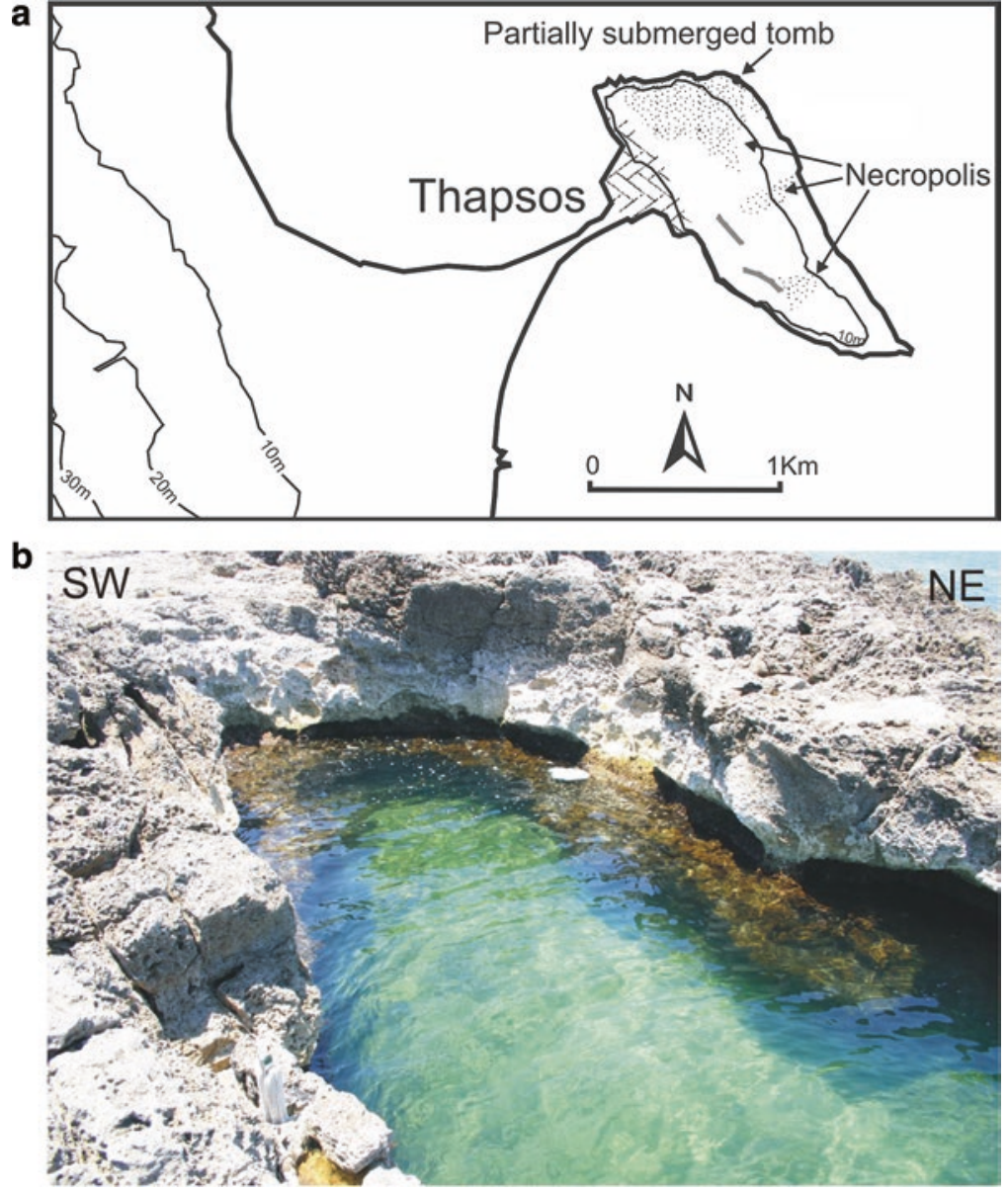

target for closer survey. There are, of course, risks that archaeological deposits will have been washed out of coastal caves by wave action during submergence, but the remains in the Sardinian caves of Grotta Verde and Grotta dei Cervi show that sufficient may be preserved to provide valuable information. The presence of onshore coastal caves with archaeological deposits provides another potential starting point in searching for underwater caves as in the example of the Ficarella cave at Grotta dell'Uzzo and the Cala dell'Alabastro at Riparo Blanc.

Another potential target is palaeoshorelines that provided natural harbours and protection for boats. The case of Cala Tramontana shows the importance of safe access for boats and the importance of local conditions in facilitating early visits to offshore islands. It also demonstrates how radically shoreline topography may change, even with relatively small changes in sea level, and that the modern coastal topography may be a very poor guide to conditions in earlier periods.

A second point is that there is considerable expertise in Italian underwater archaeology. Much of that expertise has been devoted to shipwrecks, underwater remains of Etruscan and Roman settlements or shoreline structures, and the search for archaeological or geological markers of submerged palaeoshorelines. However, the case of Cala Tramontana shows that surveys motivated by the investigation of shipwrecks may also reveal prehistoric Stone Age finds on the seabed nearby and that the search for prehistoric material can be efficiently combined with investigations of submerged historical material and sea-level indicators (see also Rovere et al. 2011b). 
The Bronze Age finds are of interest in demonstrating how much damage can be caused by marine erosion even to such substantial structures as rock cut tombs, as in the example of Thapsos. But equally, they demonstrate what can survive once submerged, as in the example of the flagstones, potsherds, and animal bones of the Scala di Furno settlement. The same point can be made about the Cala Tramontana material. Both demonstrate that open-air archaeological deposits can survive the potentially damaging effects of marine inundation and be discovered on the seabed. There may be problems of mixing of material from different periods or cases where the underwater finds have been displaced from their primary position by marine currents and redeposited, an issue identified, for example, at Cala Tramontana (Abelli et al. 2016, pp. 107-108). But these problems can, in principle, be solved by appropriately designed geoarchaeological analysis.

Finally, we emphasise that there has been a strong maritime aspect to Italian prehistory for at least the past 100,000 years, with evidence that coastlines were of interest throughout this time span, initially as sources of marine food from at least the Mousterian period, later from at least pre-Neolithic times as starting points for some form of seafaring to reach offshore islands, and from the earliest Neolithic period onwards as a focus for coastal settlement, agricultural dispersal, and trade in obsidian and other goods. The dates for the earliest examples of these activities remain unclear, and the evidence currently available hints at the possibility that some of them may go further back in time than previously thought. Moreover, sea levels were lower than present throughout this time span, certainly well into the Neolithic period, and in some regions until the Bronze Age or later because of isostatic and tectonic movements. It follows that the palaeoshorelines where most of the archaeological evidence for early coastal activity is likely to be concentrated are now under water, a point that should provide a powerful motivation for developing future investigation of Italy's underwater prehistory.

\subsection{Management of the Underwater Cultural Heritage}

The central government agency responsible for underwater archaeology is the Italian Ministry for Cultural Heritage and Tourism (M.I.B.A.C.T., Ministero per i Beni e le Attività Culturali e del Turismo), while the investigation and management of underwater cultural heritage at the regional level is the responsibility of the local 'Soprintendenze', with the exception of the Autonomous Region of Sicily. The last, in fact, is the only region of Italy governed by the 'Superintendence of the Sea' responsible for the protection, evaluation, and management of the cultural, natural, and underwater heritage of Sicily and its adjacent islands and part of the Department for Cultural Heritage and Sicilian Identity (Regione Siciliana Assessorato Beni Culturali Identità Siciliana). Italy is a party to the UNESCO 2001 Convention on the Protection of the Underwater Cultural Heritage and, as a member of the European Union, is subject to EU regulations about attention to underwater cultural heritage in Environmental Impact Assessments conducted by offshore developers (see Chapters in Part IV of this volume), but there are not yet any examples of new information on submerged landscapes or underwater prehistory recovered in this way.

Acknowledgements We thank Nic Flemming and all the other SPLASHCOS members for their continued cooperation and support, and Sebastiano Tusa, Carmelo Monaco, Giovanni Scicchitano, Rita Melis, Fulvia Lo Schiavo, Margherita Mussi, Flavio Enei, Luisanna Usai, and Daniela Rovina for information about sites which are still under study. Author contributions: EFCB, FA, fieldwork, research, analysis, and writing; GB, research, analysis, and writing.

\section{References}

Abelli L, Agosto MV, Casalbore D, Romagnoli C, Bosman A, Antonioli F, Pierdomenico M, Sposato A, Chiocci FL (2016) Marine geological and archaeological evidence of a possible pre-Neolithic site in Pantelleria Island, Central Mediterranean Sea. In: Harff J, Bailey G, Lüth F (eds) Geology and archaeology: submerged 
landscapes of the continental shelf. Geological Society, London, Special Publications 411, pp 97-110

Alfonso C, Auriemma R, Scarano T, Mastronuzzi G et al (2012) Ancient coastal landscape of the marine protected area of Porto Cesareo (Lecce, Italy): recent research. Int J Soc Underwater Technol 30(4):207-215

Antonioli F, Ferranti L, Lo Schiavo F (1996) The submerged Neolithic burials of the Grotta Verde at Capo Caccia (Sardinia, Italy) implication for the Holocene sea-level rise. Memorie Descrittive del Servizio Geologico Nazionale 52:329-336

Antonioli F (1997) Problematiche relative alle variazioni recenti del livello del mare e sue interazioni con le comunità preistoriche. In: Tusa S (ed) Prima Sicilia, alle origini della società siciliana. Ediprint, Palermo, pp 146-155

Antonioli F, Ferranti L, Lambeck K, Kershaw S, Verrubbi V, Dai Pra G (2006) Late Pleistocene to Holocene record of changing uplift rates in southern Calabria and eastern Sicily (Southern Italy, Central Mediterranean Sea). Tectonophysics 422:23-40

Antonioli F, Dorefice M, Ducci S, Firmati M, Foresi LM, Graciotti R, Perazzi P, Panatloni M, Principe C (2011) Palaeogeographic reconstruction of northern Tyrrhenian coast using archaeological and geomorphological markers at Pianosa island (Italy). Quater Int 232:31-44

Antonioli G, Lo Presti V, Morticelli MG, Bonfiglio L, Mannino MA, Palombo MR, Sannino G, Ferranti L, Furlani S, Lambeck K, Canese S, Catalano R, Chiocci FL, Mangano G, Scicchitano G, Tonielli R (2016) Timing of the emergence of the Europe-Sicily bridge (40-17 cal BP) and its implications for the spread of modern humans. In: Harff J, Bailey G, Lüth F (eds) Geology and archaeology: submerged landscapes of the continental shelf. Geological Society, London, Special Publications 411, pp 111-144

Antonioli F, Chiocci FL, Anzidei M, Capotondi L, Casalbore D, Magri D, Silenzi S (2017) The central Mediterranean. In: Flemming NC, Harff J, Moura D, Burgess A, Bailey GN (eds) Submerged landscapes of the European continental shelf: quaternary paleoenvironments. John Wiley \& Sons, Chichester, pp 341-376

Atzeni E (1981) Aspetti e Sviluppi Culturali del Neolitico e della prima Età dei Metalli in Sardegna. In: Ichnussa. La Sardegna dalle origini all' età classica. Scheiwiller, Milano, pp 19-51

Auriemma R, Solinas E (2009) Archaeological sites as sea level change markers: a review. Quaternary. International 206:134-146

Benjamin J, Rovere A, Fontana A, Furlani S, Vacchi M, Inglis RH, Galili E, Antonioli F, Sivan D, Miko S, Mourtzas N, Felia I, Meredith-Williams M, GoodmanTchernov B, Kolaiti E, Anzidei M, Gehrels R (2017) Late Quaternary sea-level changes and early human societies in the central and eastern Mediterranean Basin: an interdisciplinary review. Quaternary International 449:29-57
Blanc AC (1939) Il Monte Circeo:le sue grotte paleolitiche ed il suo uomo fossile. Bollettino Reale Società Geografica Italiana 17:485-493

Blanc AC (1958/61) Industria musteriana su calcare e su valve di Meretrix chione associatà con fossili di elefante e rinocerante in nuovi giacimenti costieri del Capo de Leuca. Quaternaria 5:308-313

Blanc AC, Segre AG (1953) Le Quaternaire du Monte Circeo. Livret-Guide, IV ème Congrès INQUA. Roma, pp. 23-108 Excursion au Mont Circé. INQUA, IV ${ }^{\circ}$ Congrès International. Roma-Pisa

Bonfiglio L, Piperno M (1996) Early faunal and human populations. In: Leighton R (ed) Early societies in Sicily. New developments in archaeological research. Accordia Specialist Studies on Italy, Volume, vol 5. University of London, Accordia Research Centre, pp 21-30

Castagnino Berlinghieri EF (2011) Subsistence, mechanisms of interaction and human mobility in the Neolithic western Mediterranean: the nature of the occupation of Lipari (Aeolian Islands, Sicily). In: Phoca Cosmetatou P (ed) The first Mediterranean islanders: Initial occupation and survival strategies. Oxford University School of Archaeology, Monograph Series, vol 73, pp 109-139

Colonese AC, Mannino MA, Bar-Yosef Mayer DE, Fa DA, Finlayson JC, Lubell D, Stiner MC (2011) Marine mollusc exploitation in Mediterranean prehistory: an overview. Quater Int 239:86-103

Compagnoni B (1991) La malacofauna del sito mesoneolitico della Grotta dell'Uzzo (Trapani). Rivista di Scienze Preistoriche 43:49-72

Dawson H (2013) Mediterranean voyages: the archaeology of island colonisation and abandonment. Routledge, London

Depalmas A, Melis RT (2010) The Nuragic people: their settlements, economic activities and use of the land, Sardinia, Italy. In: Martini IP, Chesworth W (eds) Landscapes and societies: selected cases. Springer, Dordrecht, pp 167-186

Ducci S, Perazzi P (1998) Una testimonianza del Neolitico a ceramica impressa cardiale nel'ArcipelagoToscano: l'isolotto della Scola presso l'Isola di Pianosa (LI). Atti XIII Congr. UISPP, Forli 1996, vol 3, sez 9, pp 425-430

Ducci S, Perazzi P (2000) I Neolitico antico dell'Arcipelago Toscano. In Tozzi C, Weiss MC (eds) Les premiers peuplements Holocènes de 1'aire corsotoscane. Il primo popolamento olocenico dell'area corso-toscana. Progeto Interreg II, Corsica 19971999. Pisa, pp 53-56

Ferranti L, Antonioli F (1994) La grotta sommersa ed il Riparo Blanc a san Felice Circeo. Memorie della Società Speleologica Italiana 6:137-142

Ferranti L, Antonioli F, Mauz B, Amorosi A, Dai Prà G, Mastronuzzi G, Monaco C, Orrù P, Pappalardo M, Radtke U, Renda P, Romano P, Sansò P, Verrubbi V (2006) Markers of the last interglacial sea level high 
stand along the coast of Italy: tectonic implications. Quater Int 145-146:30-54

Floris R, Melis RT, Mussi M, Palombo MR, Iacumin P, Usai A, Mascia F (2012) La presenza umana nella Sardegna centro occidentale durante l'Olocene antico: il sito di S'Omu e S'Orku (Arbus, VS). Atti della XLIV Riunione Scientifica. La preistoria e la protostoria della Sardegna. Cagliari, Barumini, Sassari 23-28 novembre 2009. Istituto Italiano di Preistoria e Protostoria, Firenze, pp 999-1004

Klein Hofmeijer G, lderliesten C, Van Der Borg K, Houston CM, De Jong AFM, Martini F, Sanges M, Sondaar PY, de Visser JA (1989) Dating of the upper pleistocene lithic industry of Sardinia. Radiocarbon 31(3):986-991

Lambeck K, Antonioli F, Purcell A, Silenzi S (2004) Sealevel change along the Italian coast for the past 10,000 yrs. Quater Sci Rev 23:1567-1598

Lambeck K, Antonioli F, Anzidei M, Ferranti L, Leoni G, Scicchitano G, Silenzi S (2011) Sea level change along the Italian coast during the Holocene and projections for the future. Quater Int 232:250-257

Lo Schiavo F (1986) Ricerche subacquee nella Grotta Verde di Alghero. Archeologia Subacquea 3. Supplemento al Bollettino d'Arte 37-38:63-67

Lo Porto FG (1990) Porto Cesareo. Insediamento protostorico di Scala di Furno. In: D’Amicis A (ed) Archeologia dei Messapi. Edipuglia, Bari, pp 221-232

Mussi M (2002) Earliest Italy: an overview of the Italian Paleolithic and Mesolithic. Kluwer Press, NewYork

Mannino M, Thomas KD, Leng MJ, Piperno M, Tusa S, Tagliacozzo A (2007) Marine resources in the Mesolithic and Neolithic at the Grotta dell'Uzzo (Sicily): evidence from isotope analyses of marine shells. Archaeometry 49:117-133

Mannino M, Di Salvo R, Schimmenti V, Di Patti C, Incarbona A, Sineo L, Richards MP (2011) Upper Palaeolithic hunter-gatherer subsistence in Mediterranean coastal environments: an isotopic study of the diets of the earliest directly-dated humans from Sicily. J Archaeol Sci 38:3094-3100

Mannino MA, Catalano G, Talamo S, Mannino G, Di Salvo $\mathrm{R}$ et al (2012) Origin and diet of the prehistoric huntergatherers on the Mediterranean island of Favignana (Ègadi Islands, Sicily). PLoS ONE 7(11):e49802. https://doi.org/10.1371/journal.pone.0049802

Palombo MR, Antonioli F, Lo Presti V, Mannino MA, Melis RT, Orru P, Stocchi P, Talamo S, Quarta G, Calcagnile L, Deiana G, Altamura S (2017) The late Pleistocene to Holocene palaeogeographic evolution of the Porto Conte area: clues for a better understanding of human colonization of Sardinia and faunal dynamics during the last $30 \mathrm{ka}$. Quater Int 439:117-140

Rovere A, Vacchi M, Firpo M, Carobene L (2011a) Underwater geomorphology of the rocky coastal tracts between Finale Ligure and Vado Ligure (western Liguria, NW Mediterranean Sea). Quater Int 232:187-200
Rovere A, Antonioli F, Enei F, Giorgi S (2011b) Relative sea level change at the archaeological site of Pyrgi (Santa Severa, Rome) during the last seven millennia. Quater Int 232:82-91

Scarano T, Auriemma R, Mastronuzzi G, Sansò P (2008) L'archeologia del paesaggio costiero e la ricostruzione delle trasformazioni ambientali: gli insediamenti di Torre Santa Sabina e Torre Guaceto (Carovigno, Br). Secondo Simposio Internazionale "Il Monitoraggio Costiero Mediterraneo: Problematiche e Tecniche di Misura", Napoli, 1-6 giugno 2008, CNR-IBIMET, Firenze, pp 391-402

Scarano T (2011) Refuge or dwelling place? The middle Bronze Age fortification walls of Roca (Lecce): spatial and functional analysis of Postern C. Rivista di Scienze Preistoriche 61:95-122

Scicchitano G, Antonioli F, Castagnino Berlinghieri EF, Dutton A, Monaco C (2008) Submerged archaeological sites along the Ionian coast of southeastern Sicily (Italy) and implications for the Holocene relative sealevel change. Quater Res 70:29-36

Scicchitano G, Castagnino Berlinghieri EF, Antonioli F, Spampinato CR, Monaco C (2016) Sacred landscapes and changing sea levels: New interdisciplinary data from the Early Neolithic to the present in south-eastern Sicily. In: Harff J, Bailey G, Lüth F (eds) Geology and archaeology: submerged landscapes of the continental shelf, Special Publications 411. Geological Society, London, pp 233-253

Stiner MC (1994) Honor among thieves: a zooarchaeological study of Neandertal ecology. Princeton University Press, Princeton, NJ

Stiner MC (1999) Palaeolithic mollusc exploitation at Riparo Mochi (Balzi Rossi), Italy: Food and ornaments from the Aurignacian through Epigravettian. Antiquity 73:735-54

Tanda G (1980) Il Neolitico antico e medio della Grotta Verde, Alghero. In: Atti della XXII Riunione scientifica nella Sardegna centro-settentrionale, 21-27 Ottobre 1978, IIPP, Firenze, pp 45-94

Tanda G (1987a) Nouveaux éléments pour une définition culturelle des materiaux de la Grotta Verde (Alghero Sassari, Sardaigne). In : 'Premières communautés paysannes en Méditerranée Occidentale. Actes du Colloque International du C.N.R.S. (Montpellier, 26-29 avril 1983)', Paris 1987, pp 425-431

Tanda G (1987b) Le culture preistoriche. In: Brigaglia M, Castellaccio AA, Contu E, Doneddu GS, GCR F, Lo Schiavo F, Manconi F, Mastino A, Meloni G, Tanda G, Tangheroni M, Turtas R (eds) La Provincia di Sassari: I secoli e la storia. Sassari, Amministrazione Provinciale di Sassari, vol 1987. stampa Amilcare Pizzi, Cinisello B, pp 10-22

Tusa S (1996) From hunter-gatherers to farmers in western Sicily. In: Leighton R (ed) Early societies in Sicily. New developments in archaeological research, Accordia Specialist Studies on Italy, vol 5. Accordia Research Centre, University of London, London, pp 41-56 
Tusa S (1999) La Sicilia nella preistoria, 2nd edn. Sellerio editore, Palermo

Tykot RH (1996) Obsidian procurement and distribution in the Central and Western Mediterranean. J Medit Archaeol 9(1):39-82
Wilkens B (2012) Resti faunistici dei livelli neolitici della Grotta Verde di Capo Caccia (Alghero, SS) Atti 6 Convegno Nazionale di Archeozoologia (Orecchiella, 2009), pp 125-129

Open Access This chapter is licensed under the terms of the Creative Commons Attribution 4.0 International License (http://creativecommons.org/licenses/by/4.0/), which permits use, sharing, adaptation, distribution and reproduction in any medium or format, as long as you give appropriate credit to the original author(s) and the source, provide a link to the Creative Commons licence and indicate if changes were made.

The images or other third party material in this chapter are included in the chapter's Creative Commons licence, unless indicated otherwise in a credit line to the material. If material is not included in the chapter's Creative Commons licence and your intended use is not permitted by statutory regulation or exceeds the permitted use, you will need to obtain permission directly from the copyright holder. 